\title{
Production of hypocaloric jellies of grape juice with sunflower pectin
}

by

M. L. ALARCÃO-SILVA

Inv. Auxiliar do Instituto Superior de Agronomia. Centro de Microbiologia e Ind. Agrícolas

H. G. AZINHEIRA

Estagiária de Inv. do Centro de Estudos de Produção e Tecnologia Agrícolas, IICT

\section{I. N. JANUÁRIO}

Assistente do Instituto Superior de Agronomia. Seç̧ão Aut. de Agronomia Tropical e Subtropical

M. C. A. LEITÃO

Inv. Principal do Centro de Estudos de Produção e Tecnologia Agrícolas, IICT

and

T. C. CURADO

Assistente de Inv. da ex. ENTPA, Inst. Nacional de Inv. Agrária

\section{RESUMO}

Existe um interesse crescente em alimentos hipocalóricos. Este facto conduziu ao estudo de pectinas com baixo teor de metoxilo que permite obter produtos gelificados (tais como doces e geleias) usando quantidades de açúcar muito pequenas.

Os resíduos dos receptáculos (cabeças) de girassol são uma das fontes mais ricas em pectinas com baixo teor de metoxilo, que têm a capacidade de formar 
geis, se existirem disponíveis no meio, em proporção adequada, iões divalentes (geralmente cálcio).

No seguimento das actividades anteriores sobre a caracterização físico-química da pectina de girassol (Alarcão-Silva, 1990; Leitão et al., 1995) e sobre a utilização tecnológica no fabrico de geis hipocalóricos (Alarcão-Silva et al., 1992), pretende-se com este contributo estudar o comportamento desta pectina na confecção de geleias e avaliar as suas características organoléticas.

\section{SYNOPSIS}

The increasing interest of low-caloric foods in diet is well known. This fact has led to the study of low-methoxyl pectins that allow to obtain jellified products (such as jams, jellies, marmalade) by using very small quantities of sugar.

Sunflower head residues are one of the richest sources of low-methoxyl pectin, their most important property being the ability to form gels, if correct proportions of divalent ions (usually calcium) are available.

Following earlier studies about physico-chemical characterization of sunflower pectin (Alarcão-Silva, 1990; Leitão et al., 1995) and technological utilization in the manufacture of low-caloric gels (Alarcão-Silva et al., 1992), we intend with this contribution to study the behaviour of this pectin in the confection of grape juice jellies and the evaluation of their organoleptic characteristics.

\section{INTRODUCTION}

The importance of some pectic substances (pectin or pectins) either due to the great amounts that certain raw materials contain, or the existence of any specific food use, as well as its hypocholesterolemic effect (based in in vitro and in vivo studies) would explain the increasing interest on deepening physico-chemical studies of pectic substances.

Sunflower plant (Helianthus annuus L.) is an important crop in Portugal and its head residues, remaining on soil after the seeds have been removed for oil industry, are one of the richest sources of low-methoxyl pectin (ca. 19\% original dry matter), the most important property being the ability to form gels even without sugar addition, if correct amounts of divalent ions (usually calcium) are present. 
In our country, as well as in other regions of the European Union where vineyard and wine consumption are traditional, there is a great interest in diversifying grape-derivated products, especially those varieties of less enological potential. The manufacture of reduced calorie jellies and/or jams is one of the possible items to be considered. Today such products are gaining importance as an interesting segment of food market, because people are more and more aware of their beneficial effects on health.

Following previous works on physico-chemical characterisation of sunflower low-methoxyl pectins (Alarcão-Silva, 1990; Leitão et al., 1995) and technological utilisation in the manufacture of low calorie gels (Alarcão-Silva et al., 1992), this investigation was carried out to test the suitability of that pectin to the confection of grape juice reduced calorie jellies in comparison with two types of commercial pectin. Aiming at the optimisation of low-calorie jelly formula, based on consumers' preferences, the jellies were submitted to a sensory panel test judgement and instrumental texture-analysis.

\section{MATERIALS AND METHODS}

\subsection{SAMPLE COMPOSITION}

Grape juice was obtained from a 1:1 mixture of two red cultivars, "Benfica" and "Piriquita". After harvest the grapes were washed, sorted out, crushed, treated with SO2, pressed and kept at $7^{\circ} \mathrm{C}$ for three days. The juice was filtered and stored at -3 to $0^{\circ} \mathrm{C}$ using $0.06 \%$ potassium sorbate as preservative. The soluble solids content was $22^{\circ} \mathrm{Brix}$, the $\mathrm{pH} 3.3$, calcium, potassium and magnesium contents were 125,1170 and $240 \mathrm{mg} \mathrm{dm}^{-3}$, respectively.

Experimental low-methoxyl pectin was obtained from dry heads (without seeds) of sunflower (Helianthus annuus L.). The extraction of pectin was carried out according to the method of Lin et al.(1975) with slight modifications. Only oxalate-soluble fraction which was submitted to consecutive treatments of purification as described previously was considered (Leitão et al., 1995). 
The standard low-methoxyl commercial pectins used were Violettband D-075 (amidated pectin) and Violettband Rein (non-amidated pectin) provided by OBIPEKTIN AG (Switzerland).

\subsection{JELLIES PREPARATION}

The grape jellies were made using the pectin concentrations of $0.5,0.75$, and $1 \%$ for the three types of essayed pectin.

The formula (Table 1) and the general procedure used in the preparation of the low-calorie jellies was as follows: the pectin was blended with $25 \%$ its weight in sugar, dispersed in hot water with magnetic stirring and added to the grape juice previously heated at $60-70{ }^{\circ} \mathrm{C}$. The mixture juice-pectin was heated with continuous stirring to ensure full suspension of pectin. The remaining sugar was incorporated when temperature approaches $70^{\circ} \mathrm{C}$ and heating stopped after the mixture reached $39^{\circ} \mathrm{Brix}$ (refractometer reading). Then it was poured into glass containers, kept at $-18^{\circ} \mathrm{C}$ for 15 minutes and stored at $4^{\circ} \mathrm{C}$ until evaluation of jellies quality characteristics.

TABLE 1

Jellies experimental formula

\begin{tabular}{ll}
\hline Ingredients & Amounts $(\mathrm{g})$ \\
\hline Pectin & $1 ; 1.5 ; 2$ \\
Sugar & 52 \\
Water & 50 \\
Grape juice & 100 \\
\hline
\end{tabular}

\subsection{SENSORY EVALUATION}

The jellies (20 sets) were submitted to a sensory panel (ten panellists from the laboratory staff with some experience in sensory evaluation) requested to give a score (from low to high in a 
non-structured $10 \mathrm{~cm}$ scale) to each of the following characteristics: aroma (intensity), taste (sweet, acid and intensity), texture (hardness, spreadability) and overall acceptance.

Tests took place in a standardised test room provided with individual booths and the trials assessed in four sessions with five randomly grouped samples at each time.

\subsection{TEXTURE-PROFILE ANALYSIS}

The textural characterisation of the jellies was made by using the empirical technique of Texture-Profile Analysis (TPA) that allows the evaluation of the following parameters: fracturability, hardness, cohesiveness, adhesiveness, springiness, gumminess and chewiness.

The samples were analysed on a TAX T2 Texture Analyser programmed for the following conditions: a cylindrical plunger with 1 in. diameter; contact force of $5 \mathrm{~g}$, contact area of 284.88 $\mathrm{mm}^{2}$, speed of $2 \mathrm{~mm} \mathrm{~s}^{-1}$ and a $5 \mathrm{~s}$ interval between the first and second bites.

The experiments made in triplicate were performed at room temperature.

\section{RESULTS AND DISCUSSION}

\subsection{PHYSICAL CHARACTERISTICS OF LOW-CALORIE JELLIES}

In this study we intend to investigate if a correlation between sensory evaluation and instrumental measurements of the low-methoxyl pectin jellies could be established.

Texture profile analysis is an empirical technique of double-penetration that simulates two bites of the jaw action. Data obtained from the Force-time plots enable the evaluation of seven texture parameters.

Hardness is an estimation of the required force to penetrate jelly (peak force during the first bite). The results showed that jellies prepared with non-amidated pectin had such a low hard- 
ness that values could not be measured in the used instrumental conditions. Therefore the non-amidated pectin will not be considered in the other parameters interpretation. This fact agrees with the general information that non-amidated pectins usually require more calcium ions than those already present in the juice for a good gelation (Pedersen, 1980; Pilgrim et al., 1991).

As far as amidated pectin and the sunflower pectin for range concentration under study $(0.5,0.75$ and $1 \%)$ are concerned, the behaviour of jellies was similar, hardness values increasing for higher concentration levels (Fig. 1). The lowest value was registered for $0.5 \%$ amidated pectin and a maximum was reached at $1 \%$ of the same pectin.

FIGURE 1

Hardness, springiness and cohesiveness vs. pectin concentration

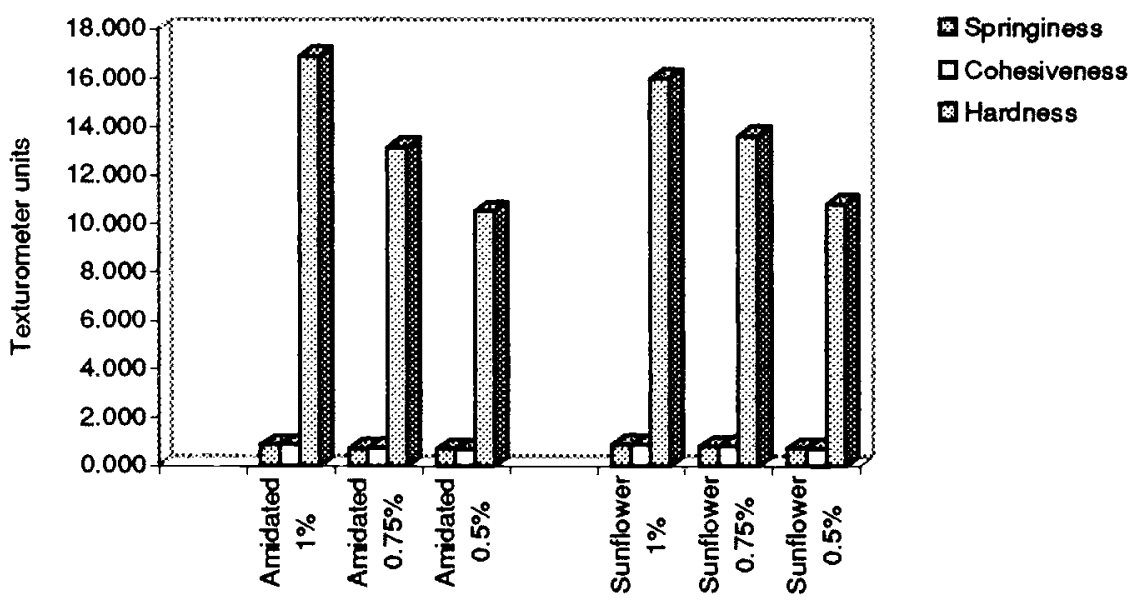

The cohesiveness that represents the work required to overcome the internal bonds of the sample (jelly) shows an increase with the pectin content of jelly and there are no apparent differences between the two types of pectin considered (Fig. 1). 
Similar behaviour was observed for springiness (elasticity) which is given by the time that the material spends to recover its non-deformed condition after the first bite (Fig. 1). Adhesiveness, defined as the work necessary to overcome the attractive forces between the surface of the sample and the surface of other materials with which the food comes into contact, e.g. tongue, teeth, palate, etc. (Szczesniak, 1963), is given on the texturometer curve by the negative force area, representing the work needed to pull out the plunger from the sample. This parameter's value may be considered an evaluation of stickiness of jelly. Fracturability, also called brittleness, is given by the measure (\%) of the plunger path into the jelly when it breaks.

The jellies analysed had no stickiness at all and were non-brittle for the levels tested. This finding, especially as far as sunflower pectin is concerned is quite different from what could be expected, based on Chang and Myamoto's results (Chang \& Myamoto, 1992).

The evaluation of two other parameters results from simple arithmetics: gumminess is the product of hardness $\times$ cohesiveness and chewiness is given by the product of hardness $\times$ cohesiveness $\times$ springiness.

The results obtained for the analysed jellies are shown in $\mathrm{Fi}$ gure 2. As one would expect, both parameters increase with pectin concentrations as it was likewise observed with hardness, cohesiveness and springiness.

\subsection{SENSORY ANALYSIS}

The evaluation of some parameters was quite discrepant probably due to the resort to a non-trained panel. Nevertheless all the answers were considered (maximum value for standard deviation being \pm 3.0 , results not shown).

The data from sensory evaluation and texture profile analysis of the jellies made with amidated pectin and sunflower pectin were subjected to Principal Component analysis $(\mathrm{PC})$ using the statistical software based on Jacobi method (Lebart \& Morineau, 1985). The results of $\mathrm{PC}$ analysis are shown in Figure 3. The plane of two principal components $(\mathrm{F} 1, \mathrm{~F} 2)$ explain $89.75 \%$ of the variance contained in the original data. The attributes related 
with textural evaluation are highly correlated with the first principal component (Hard $=0.95, \mathrm{Spr}=0.97, \mathrm{Che}=0.98, \mathrm{Gum}=0.95$, $\mathrm{Coe}=0.98, \mathrm{HS}=0.82$ and $\mathrm{SP}=-0.93$ ). As it could be expected, spreadability increases along the negative side of the axis unlike other textural parameters.

\section{FIGURE 2}

Gumminess and chewiness vs. pectin concentration

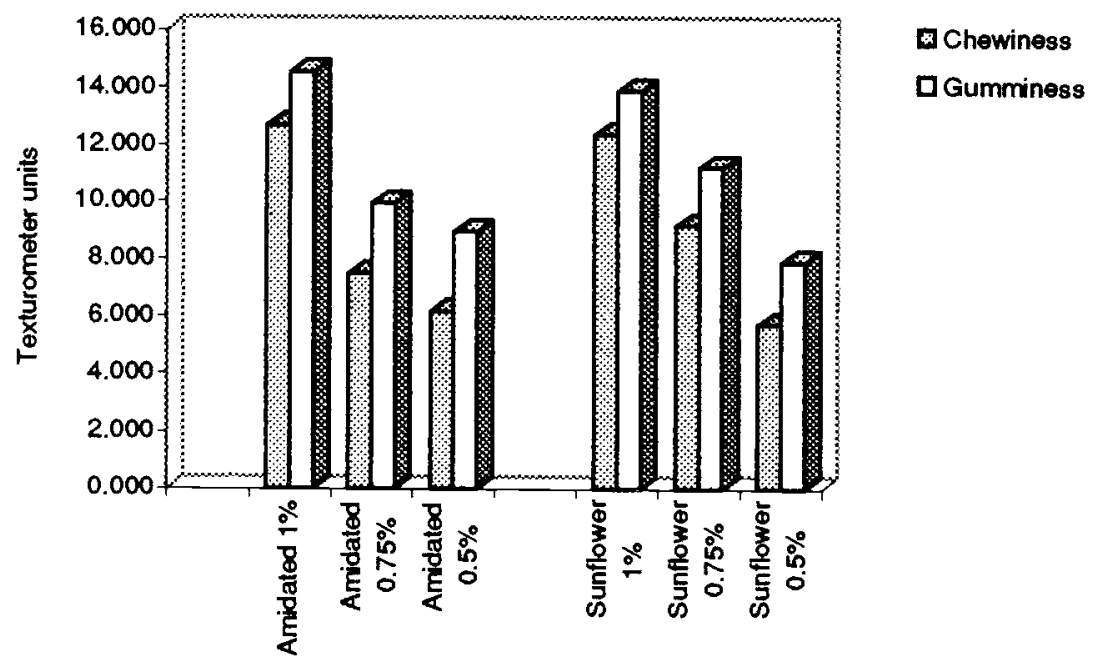

The overlapping of textural attributes suggests that characterisation of this kind of jellies could be based on the evaluation of a single parameter. The concept of hardness being the easiest to apprehend and due to its close relation with the same sensory attribute, we believe that when jellies are to be appreciated from a textural point of view, hardness may be measured on its own.

Overall acceptance is an attribute that seems to be influenced either by textural attributes or the flavour ones. However it is possible to establish correlations between overall acceptance and hardness (Figs. 4, 5, 6, 7). 


\section{FIGURE 3}

Plotting of jellies (6) and variables (12) on a plane formed by the first and second principal components, F1,F2

F2

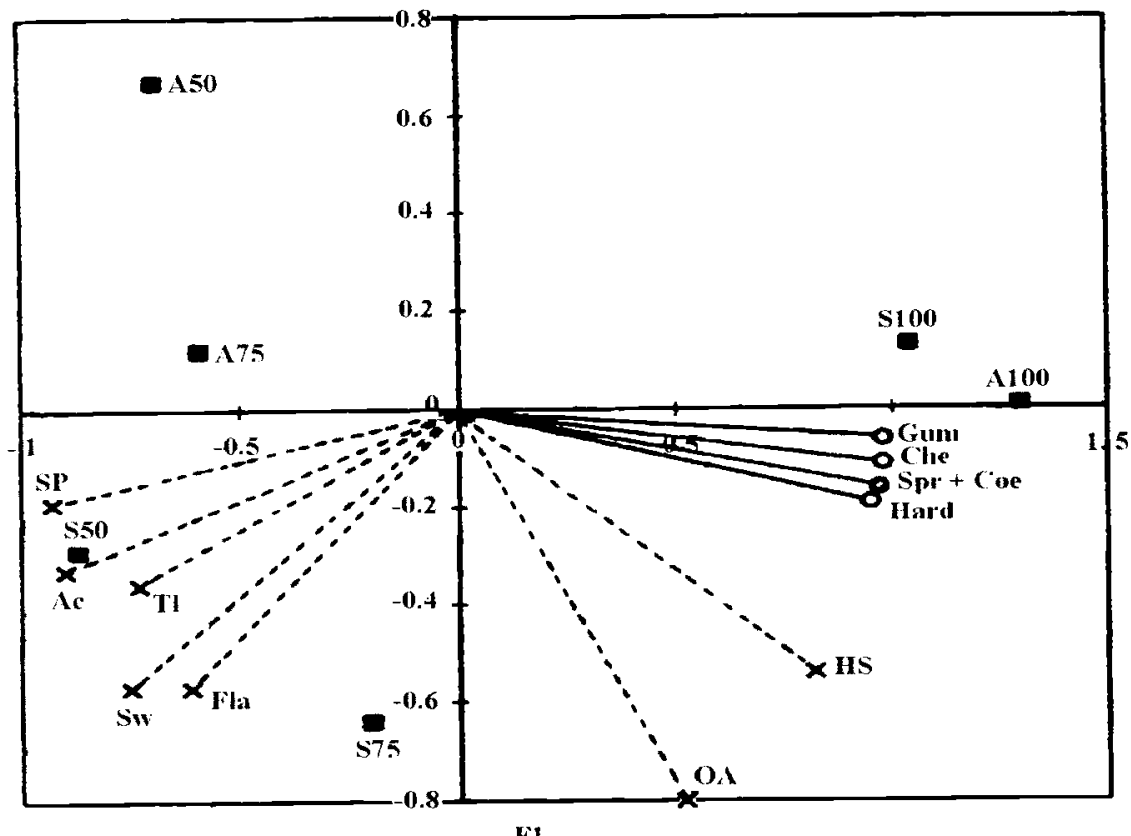

F1

Hard $=$ Hardness; Spr= Springiness; Ch $\theta=$ Chewiness; Gum $=$ Gumminess; $\mathrm{Coe}=$ Cohesiviness; HS= Sensory hardness; $\mathrm{SP}=$ Spreadability; $\mathrm{AC}=\mathrm{Acid}$; $\mathrm{S} W=$ Sweet $; \mathrm{Fla}=\mathrm{Flavour} ; \mathrm{Tl}=$ Taste intensity; $\mathrm{OA}=$ Overall acceptance .

\section{FIGURE 4}

Correlation between overall acceptance and hardness (jellies made with sunflower pectin)

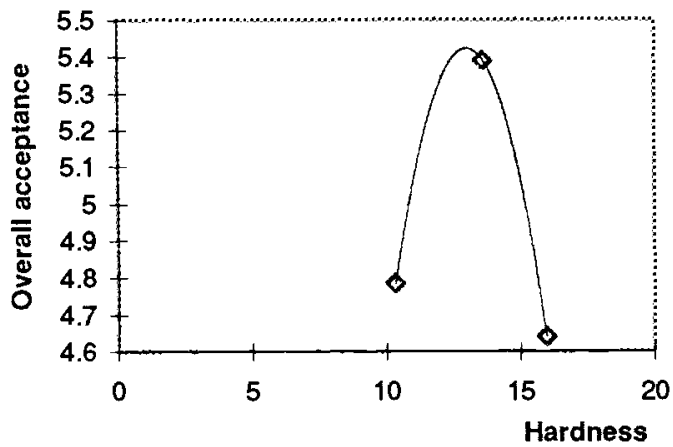

$$
\begin{gathered}
y=-0.0899 x^{2}+2.3389 x-9.7961 \\
R^{2}=1
\end{gathered}
$$


FIGURE 5

Correlation between overall acceptance and sensory hardness

(jellies made with sunflower pectin)

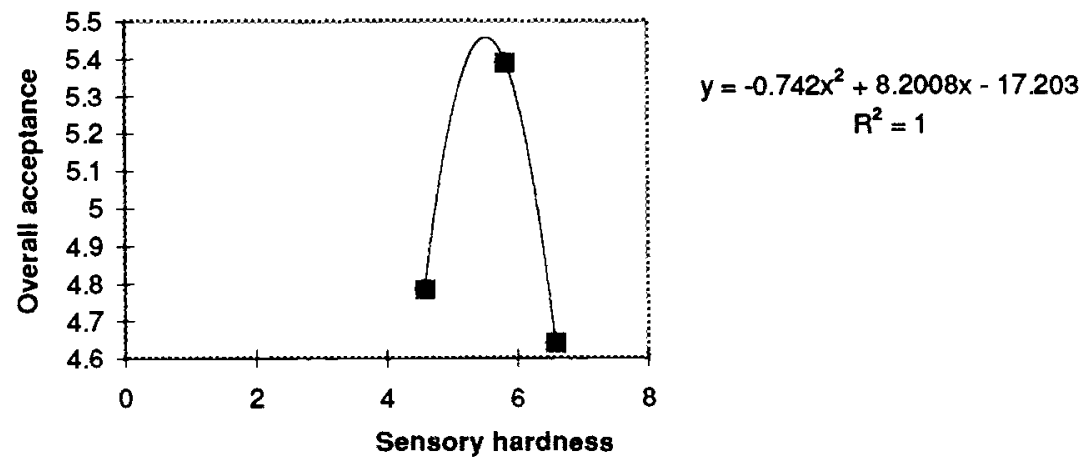

FIGURE 6

Correlation between overall acceptance and hardness (jellies made with amidated pectin)

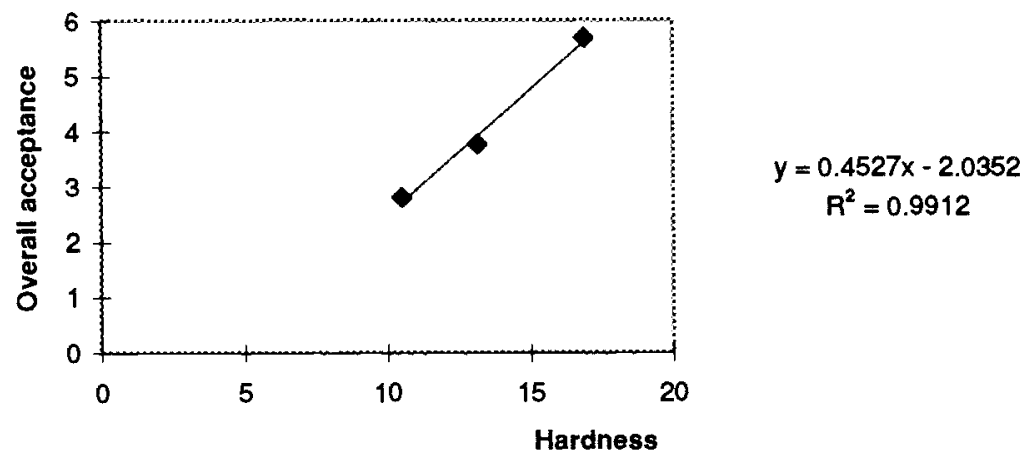

FIGURE 7

Correlation between overall acceptance and sensory hardness (jellies made with amidated pectin)

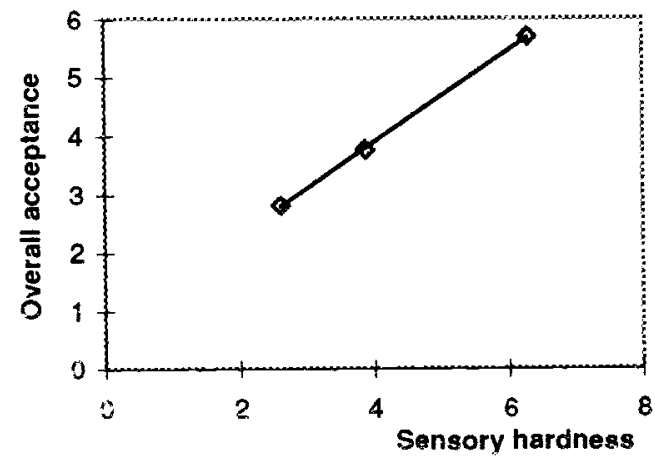

$$
\begin{gathered}
y=0.781 x+0.759 \\
R^{2}=0.9998
\end{gathered}
$$


The jellies made with sunflower pectin and amidated pectin (level 1\%) are very similar (in so far as texture is concerned) but as the polynomial correlation (degree 2) suggests, above $0.7 \%$ of sunflower pectin the overall acceptance decreases probably due to the appearance of perceived in-mouth sensations described as "greasy" and "clammy" and leading to an unfavourable appreciation.

A decrease in the perception of taste and aroma of the jellies has been noted when hardness increases, which agrees with Chai et al.(1991) who refer a reduction in the perception of flavour intensity with an increase of gel rigidity which may be related with the available surface area of gel exposed on chewing.

\section{CONCLUSION}

From the results of this study it appears that commercial amidated and experimental sunflower pectins have similar behaviours and from a consumer's point of view there are only small differences mainly related with a visual evaluation of the jellies, and "greasy" and "clammy" tastes.

Jellies made with sunflower pectin show small air bubbles that could be responsible for the slight opacity observed; with amidated pectin jellies are very transparent as it is also referred by several authors.

The good results obtained in the production of jellies with experimental sunflower pectin are all the more interesting as this pectin has not suffered any standardisation process like the commercial ones. Such a process could eventually overcome the undesirable characteristics mentioned above.

Although this study needs further work it is thought to give some contribution to a better understanding of the behaviour of low-methoxyl sunflower pectin in food technology namely in reduced calorie jellies or jams. The results obtained corroborate the interest, already suggested by the authors, in using sunflower agricultural wastes as an important source of natural low-methoxyl pectin for these purposes. 


\section{ACKNOWLEDGMENTS}

We thank Elsevier Science - NL, Sara Burgerhartstraat 25, $1055 \mathrm{KV}$ Amsterdam, The Netherlands, for kind permission to reprint the communication to be published in Proceedings of Pectins and Pectinases (expected publication date September 1996).

\section{REFERENCES}

Alarcão-Silva, M.L. (1990) - Characterization of a pectin from sunflower head residues. Acta Alimentaria, 19: 19-26.

Alarcão-Silva, M.L.; Curado, T.C.; Sousa, I.M.N. (1992) Gelificados hipocalóricos de um sumo de uva por incorporação de pectina com baixo teor de metoxilo extraída de resíduos de girassol. Actas das I Jornadas das Indústrias Agro-Alimentares, ISA, Lisboa, 2: 153-169.

Chai, E.; Oakenfull, D.G.; McBride, R.L.; Lane, A.G. (1991) - Sensory perception and rheology of flavoured gels. Food Australia, 43: 256-257.

Chang, K.C.; Miyamoto, A. (1992) - Gelling characteristics of pectin from sunflower head residues. J. Food Sci., 57: 1435-1443 .

Lebart, L.; Morineau, A. (1985) - Système Portable pour l'Analyse des Données (SPAD). Paris.

Leitão, M.C.A.; Alarcão-Silva, M.L.; Januário, M.I.N.; AzINHEIRA, H.G. (1995) - Galacturonic acid in pectic substances of sunflower head residues: quantitative determination by HPLC. Carbohydr. Polym., 26: 165-169.

LiN, M.J.Y.; SOSUlski, F.W.; HumberT, E.S.; DOWNEY, R.K. (1975) - Distribution and composition of pectins in sunflower plants. Can. J. Pl. Sci., 55: 507-513.

Pedersen, J.K. (1980) - Carrageenan, pectin and xanthan/locust bean gum gels. Trends in their food uses. Food Chem. 6: 77-88.

Pilgrim, G.W.; Walter, R.H.; Oakenfull, D.G. (1991) - Jams, jellies and preserves. In Reginald $\mathrm{H}$. Walter (ed.), The Che- 
mistry and Technology of Pectin. Academic Press, London. pp. 23-50.

SZCZESNIAK, A.S. (1963) - Classification of textural characteristics. J. Food Sci., 28: 385-389. 